\title{
Kurdish Women's Subjectivity: a Target of Patriarchal Power: A Foucaultian Perspective
}

\author{
Abdulkhaliq Yaqubi ${ }^{1}$
}

Received: May 11, 2016

Reviewed: June 13, 2016

Accepted: June 20, 2016

\begin{abstract}
In Foucault's theories no ethical system can be established outside its social framework, and that is why subjectivity and some of its important manifestations like body and its behavior are figured, or, more accurately according to Foucault's terminology, are colonized, by a variety of forces. What this paper suggests is introducing patriarchy both as a disciplinary, though traditional, institution and one of the regulating forces leading in colonizing of Kurdish women's subjectivity and bodies as well. In fact, the paper shows that it is patriarchy, as a dominant system of bipower in Kurdish society, which prepares the condition in which women's subjectivity becomes the target of exercising of repressive power. For this purpose, first of all, the paper discusses why patriarchy should be considered as a system of biopower in which power serves first and foremost a system of domination which can hold its main interests if it deprives women of their subjectivity. Secondly, it examines for what reason Kurdish patriarchy represents a repressive power in which Kurdish women's subjectivity and body are turned into the territories of colonization. And last but not least, from the perspective of Foucault's theories concerning power the paper explores how Kurdish nationalism as a patriarchal discourse aims at colonizing of women's subjectivity.
\end{abstract}

Keywords: Kurdish women, patriarchy, bipower, Kurdish nationalism

\section{Recommended citation:}

Yaqubi, A. (2016). Kurdish women's subjectivity: A target of patriarchal power: A Foucaultian perspective. International Journal of Kurdish Studies 2 (3), 1 - 8

\footnotetext{
${ }^{1}$ Lecturer, Media Department, Cihan University Erbil, Kurdistan Region - F.R. Iraq. E-mail: Yaghoobi74@yahoo.com
} 


\section{INTRODUCTION}

In most of Foucault's theories, especially those that raise important questions concerning biopolitics and biopower, a careful attention is given to 'subjectivity' as a site, or ' the local centre', of power-knowledge. But subjectivity in his works is not a territory independent of social context; on the contrary, it is constituted through relations of power and, according to his special term, 'a game of truth' (Foucault, 1988, p. 117). In other words, in Foucault's theories no ethical system can be established outside its social framework, and that is why subjectivity and some of its important manifestations like body and its behavior are figured, or, more accurately according to Foucault's terminology, are colonized, by a variety of forces. What I suggest in this paper from a Foucaultian point of view is introducing patriarchy both as a disciplinary, though traditional, institution and one of the regulating forces leading in colonizing of Kurdish women's subjectivity and bodies as well. In fact I try to show that it is patriarchy, as a dominant system of bipower in Kurdish society, which prepares the condition in which women's subjectivity becomes the target of exercising of repressive power. For this purpose, first of all, I discuss why patriarchy should be considered as a system of biopower in which power serves first and foremost a system of domination which can hold its main interests if it deprives women of their subjectivity. Secondly, I examine for what reason I consider Kurdish patriarchy a repressive power in which Kurdish women's subjectivity and body are turned into the territories of colonization. And last but not least, from the perspective of Foucault's theories concerning power I explore how Kurdish nationalism as a patriarchal discourse aims at colonizing of women's subjectivity.

\section{Patriarchy: A System of Biopower}

I see patriarchy as a kind of cultural capital, in its Bourdieuian sense, on which the authority of man, and not woman, is based. This kind of capital, like any other, has its own value determined by different social forces within a social field. On the other hand, when this cultural is used in social relations in practice, it provides a condition in which a special kind of power-knowledge system is brought into play, that is to say, the condition of manifestation of biopower is born. But first let us see what biopower is. In Foucault's theories biopower refers to the technologies, knowledges, discourses, politics and practices used to bring about the production and management of a state's human resources. Biopower analyses, regulates, controls, explains and defines the human subject, its body and behavior (Danaher, 2000, p. ix).

Biopower for Foucault, therefore, is a systematic method to examine, according to Peter Hamilton, 'social processes through which rationality is constructed and applied to the human subject, in order to make it the object of possible forms of knowledge' (Smart, 1985, p.9). Foucault himself speaks of biopower 'to designate what brought life and its mechanism into the realm of explicit calculations and made knowledge-power an agent of transformation of human life (Foucault, 1978, p. 265). In sum, in Foucault's work a special place is given to subjectivity as a crucial feature in the procedure of power relations. 
What makes a connection between biopower and patriarchy, however, is the kind of treatment of power relations that patriarchy makes use of in order to impose its determination on social processes. For example, in Kurdish society patriarchy considers 'Hijab' (veil) as a sign of honor for women, that is to say, how Hijab forms the ways in which not only women's subjectivity but also their bodies are valued. In fact, this kind of truth-making process throughout a variety of technologies, knowledges, and politics (consider how the necessity of believing in wearing Hijab is brought into the discourse of religion in general and religious duties in particular by Mullas or Kurdish clergymen) is tied up with the way in which patriarchal power is practiced. So, regarding this example, the knowledge used to sacralizing Hijab is not ahistorical, but is produced by, to use three basic terms of Foucault, epistemes, disciplines, and discourses that are, directly or indirectly, at the serve of patriarchy as one of the most central governing systems of life in Kurdish society. Consequently, patriarchy becomes an inevitable part of Kurdish individuals' socialization influencing them to monitor themselves as the subjects of their own surveillance. That is why self-gazing of bodies, actions, and feelings is an important issue of not only families, as private spheres, but also state institutions, as public spheres, like parliament when it deals with, for instance, the problem of abusing of cellophone photos.

The next point showing that patriarchy can be taken for granted as bipower is that it acts as a gazing power helping make active one of the primary principles of the contemporary societies, which Foucault names 'descending individualism' (Danaher, 2000, pp. 57-8). Using the capabilities of modernization and 'associated disciplinary apparatuses', patriarchy creates the condition in which 'descending individualism' is occurred, that is to say, "people are more closely monitored and 'individualized' the lower in the social scale they are" (Ibid., p. ix). Indeed, it can be argued that this kind of individualism leads to bring two consequences in favor of patriarchy, as one of the dominant biopowers in Kurdish society. One the one hand, because of their low social scale, women are regularly monitored, whether inside home or outside, through the kind of their body behavior. For instance, in Kurdish society the majority of young, unmarried girls should not go shopping alone for the reason that, according to patriarchal principles, they are regarded as "Za'ifa" (an Arabic word meaning weak female), and need to be gazed in order not to be spoiled ethically. So they can go shopping but only with their, for example, mothers as surveillance cameras. These cameras ensure patriarchy that the individuality of the girls operates according to its standards.

On the other hand, patriarchy obtains the authority to stay away from the inspection of the gaze of society and so keeps its interests. An example to this point would be the power of the Kurdish tribe, as a traditional, powerful part of patriarchy in Kurdish society, which can cover up any social mistreatment of itself against women in the name of 'tribal resolution'. Here tribe as a disciplinary force of patriarchy plays an important role in making 'things' invisible in order to do what they need to do on the basis of the rules of their authority, and not according to any exterior authority, say democracy-based rules in which freedom of individuality is institutionalized. As a result,

The principle of descending individualism indicates that people are made to appear as specific individuals, but the terms of this appearance are dictated by the forms of the disciplinary forces. The way in which people are made subject to various physical, academic 
and psychological examinations...the way in which females are characteristically valued in terms of their looks: all these are examples of the disciplinary power of the gaze (Danaher, 2000, p. 59).

In short, although, according to Edward W. Said, "Foucault's imagination of power is largely with rather than against it" [Said's emphasis] (Couzens Hoy, 1986, p. 152), I think patriarchy as a biopower provides a condition in which certain social groups or social organizations have more opportunities to determine how the sources of power are distributed and exercised in order to control women's subjectivity. Consequently, patriarchy can be able to bring about the process of, to use Foucault's terminology, producing 'docile' bodies and minds of women through its technologies and discourses. For that reason not only the fundamental suggestion but also the most economical kind of surveillance of the doctrines of patriarchy is to make self-gazing women. In the next part of the paper I will argue Kurdish patriarchy as a repressive kind of power within the context of Kurdish society in more details.

\section{Kurdish Patriarchy: A repressive Power to colonize Women's Subjectivity}

Patriarchy like any other ethical system is determined by its social context, by the sorts of knowledge and technology that are compelling in a particular context, and by relations of power (Danaher, 2000). In order to discern this social context there are some vital questions needed to be examined. Why does patriarchy in the contemporary world, especially Kurdish patriarchy contained by a semi-traditional society, have to be considered a repressive, or maybe better to say, according to Foucault in his latest works like "The History of Sexuality", a non-productive power? What are those institutions and organizational techniques and discourses in Kurdish society, namely the resources of Kurdish patriarchy, that have the authority to regulate, control, and colonize women's body in order to ensure that women's subjectivity does not fail to meet the conditions they characterize as normal? On the basis of which kinds of knowledge does Kurdish patriarchy consider itself a 'rational, self-governing' subject but women as 'non-rational, man-dependent' subject? I comment on some points in order to examine the abovementioned questions.

The main point regarding Kurdish patriarchy is that the power it exercises is more often than not repressive. Although Foucault asserts that the notion of repression is a more insidious one, or at all events I myself have had much more trouble in freeing myself of it, in so far as it does indeed appear to correspond so well with a whole range of phenomena which belong among the effects of power....But it seems to me now that the notion of repression is quite in adequate for capturing what is precisely the productive the aspect of power....If power were never anything but repressive, if it never did anything but to say no, do you really think one would be brought to obey it? (Foucault, 1980, pp. 118-9)

It seems to me that patriarchal power can never be considered productive when it is directed to colonize women's subjectivity. In fact I do not deny the existence of any productive aspect of power in general ( for example, see how women stimulate to defend the independence of their subjectivity when they decide to face up to the superiority of patriarchal discourse), but what I emphasize is that patriarchy makes use of the repressive feature of 
power in order to colonize women's subjectivity for its own purposes. In addition, most of sociologists suppose that Foucault himself focuses on this side of power when he deals with the relationship between power, subjectivity, and agency. For instance, Amy Allen has referred to this point in the way that,

For Foucault, power is both productive and repressive, both enabling and constraining. Moreover, it is the intertwining of the productive and repressive aspects of power that is the key to understanding between power, subjectivity, and agency in Foucault's work. Foucault became famous for claiming that the individual subject is one of the primary effects of this productive/repressive, enabling/constraining power (Allen, 2002, p.135).

That is why, I think, power in patriarchal system should be recognized as repressive when it is exclusively aimed at colonizing women's subjectivity and body, but at the same time I accept that "Foucault's claim that the individual is an effect of power does not commit him to the much stronger claim that the individual is merely or nothing more than [emphasis is Allen's] an effect of power" (Ibid,. p. 136). In short, I understand Kurdish patriarchy as an ethical system, based on a special kind of cultural capital which is rooted in some dominant discourses in the history of Kurdish society such as tradition, religion, tribalism, and nationalism, constituting a space, whether individual or social, in which the repressive dimension of power is working on women's subjectivity and body to be colonized. Among these discourses I only deal with two of them, i.e. nationalism and religion, which seem to be more influential in the present situation of Kurdish society.

\section{Nationalism: A representative power of patriarchy in Kurdistan}

As Arnold I. Davidson shows Foucault's proposal regarding power is that 'do not study power merely as a form of repression or prohibition... and do not reduce it to a consequence of legislation and social structure'(Couzens Hoy, 1986, pp. 225-6). Nationalism and religion, religion of course in its contemporary and even global form, in which religious ideology makes use of technology and modernization in order to create religious, ideological subjects, are two key powers which by means of their discourses play an important role in institutionalizing of patriarchy in Kurdistan. Methodologically speaking, it is important to bear in mind that one should not consider these two notions as homogeneous and premeditated because, as Foucault emphasizes, power is not merely something to be held; it has its own history, trajectory, and mechanism without which it becomes only an abstraction. This point has been clarified more in one of the most significant Foucault's comments on power,

...this will lead one to view power not as the homogeneous domination of one group or class over another, but as a net-like, circulating organization; finally, one should not analyse power at the level of 'conscious intention or decision', should not ask what certain people want and why they want to dominate others, but should ask, instead, 'how things work at the level of on-going subjugation, at the level of those continuous and uninterrupted processes, which subject our bodies, govern our gestures, dictate our behaviours, etc.', those processes which constitute us as subjects (Ibid. p. 226). 
On the basis of these comments I try to examine how nationalism and religion in Kurdish society work in the favour of patriarchy. Let us deal with nationalism first.

Nationalism as a modern discourse aims at unifying different realms of notions like ethnicity, race, class, language, and gender in the name of superiority of nation as the criterion of self-determination. That is why one the one hand, according to Sandra Phelps, "national identity is built upon the ambivalent and violating repressions of difference in the endless drive for coherence" (Phelps, 2003, p. 1). On the other, nationalism tries to colonize women's body in order to assimilate it into its own demands and requests because

It is the potentiality contained within conceptualizations of femininity that holds the simultaneous possibilities of national demarcation and of national dilution. It is her body and her subjectivity that the nation most fears; her body is the site of both the potential future of the nation as well as the greatest threat to national cohesion (Ibid. p.2).

Consequently, nationalism produces discourses in which men are shown as subjects and women as objects, men as active and women as passive. In the historiography of Kurdish nationalism women have occupied no considerable place for the reason that their body is not appropriate for 'Xebat' (fighting); in addition they have not the required rationality based on how to liberate the nation, which is the most important concern of 'Peshmarga' (man fighter). Here Kurdish nationalism works like a biopolitic power in which Kurdish women's subjectivity is shaped by the way in which their body and their bodily function are acted upon by disciplinary technologies, according to Foucault's terminology. In fact women's subjectivity is managed, organized, disciplined, and as a whole, colonized, as both national and social concern, in those institutions and discourses that nationalism brings into the play of national security or national unity.

In the beginning years of 1970 th, in which Kurdish nationalism, led by Mulla Mustafa Barzani, could establish a semi autonomous political authority for itself, unlike the previous decades in which Islamic names were common, the majority of people in Iraqi Kurdistan would choose national names for their children. For example, the names of some elements of nature, which in Arabic language are usually given to male names, like, to name a few, 'Kwestan' (mountain), 'Gulala' (rose), 'Hataw' (the sun), 'Rubar' (river), were chosen for girls. I see such practice as a consequence of those patriarchal systems of domination that Kurdish nationalism holds in its arms. In other words, Kurdish nationalism, as a prevailing discourse of Kurdish society, plays a clonising role in ordering life experiences and national responsibilities of Kurdish people, making sense of those experiences and responsibilities. As Sandra Phelps explores, this point is also true regarding the politics of nationalism in the face of femininity discussions,

It is difficult to reason that the subjects of nationalism and identity formation can be theorized in an un-gendered manner. Historical and social-political discussions of the nation and of identity formation that ignore these relationships are themselves partial, incomplete and in many ways function to reinforce existing normative exclusions. The gendered shape of nationalism is evident in the very repression of difference within these texts and as I have shown, this repression is absolutely crucial to formations of the nation. Historical and social- 
political imaginings of the realness of the nation must confront such repressions in their biased and partial imaginaries (Ibid. p. 19).

So here nationalism supports the main idea of the knowledges produced by patriarchy emphasizing that individuals have a sexual nature from which one should conclude that female individuals require protection of patriarchy; this, in its turn, leads to make the very female individuals objects of control and surveillance.

\section{CONCLUSION}

Once Foucault said, "Modern man... is the man who tries to invent himself. This modernity does not liberate man in his own being; it compels him to face the task of producing himself "(Foucault, 1984, p. 42). What patriarchy, as a system of biopower, does is providing a condition in which the task of producing subjectivity of women confronts serious social and individual impediments. Accordingly, repressive aspects of power is the key to understanding the relationship between Kurdish patriarchy on one the one hand and colonization of women's subjectivity and body on the other. Using Foucault's claim that individual subject is one of the principal effects of this repressive, constraining power (Allen, 2002, p.135), I also considered Kurdish nationalism as one of the influential representatives of patriarchal power, by which femininity is denied since it is regarded as the greatest threat to national unity. Patriarchy as one of the prominent social powers in the contemporary Kurdish society tries to organize women's subjectivity and body on the basis of its own knowledge, emphasizing on the point that sex and sexual differences are the matters of nature, the point on which the proximity of discourses between nationalism and patriarchy is based.

\section{REFERENCES}

Allen, Allen. (2002). Power, Subjectivity, and Agency: Between Arendt and Foucault.In International Journal of Philosophical studies. http://www.tandf.co.uk/journals:Taylor\& Francis Ltd. Pp.131-145.

Bevir, Mark. (1999). Foucault, Power, and Institutions. In Political Studies Association. USA: Blackwell Publishers. Pp. 345-359.

Couzens Hoy, David. (1986). Foucault: A Critical Reader. USA: Blackwell Publishers.

Danaher, Geoff and Schirato, Tony and Webb, Jen. (2003). Understanding Foucault. London: SAGE Publication.

Foucault, Michel. (1980). Power/knowledge: Selected Interviews and Other Writings, ed. Colin Gordon. New York: Pantheon Books.

Foucault, Michel. (1976). Histoire de sexualite, Vol. 1, La Volonte de savoir, English edn (1978). The History of Sexuality: Vol. 1, an Introduction, trans. Robert Hurley. Harmondsworth: Penguin. 
Foucault, Michel. (1984). Histoire de la sexualite, Vol.2, L Usage des plaisirs, English edn 1985. The History of Sexuality: Vol. 2, The Use of Pleasure, trans. Robert Hurley. Harmondsworth: Penguin.

Foucault, Michel. (1984). The Repressive Hypothesis. In Paul Rabinnow (ed) The Foucault Reader: An Introduction to Foucault's Thought. London: Penguin.

Phelps, Sandra. (2003). The Conundrums of Modern Identity, Nation and Meaning. Center for peace and conflict studies, occasional papers. Sydney: Usyd.

Smart, Bart. (1985). Michel Foucault. London and New York: Routledge. 